\title{
Practice Patterns and Adequacy of Maintenance Hemodialysis in Rio Grande, RS, Brazil
}

\author{
Luiz Eduardo Corrêa Schein ${ }^{*}{ }^{\mathbb{D}}$, Juraci Almeida Cesar ${ }^{2}$ \\ ${ }^{1}$ Faculty of Medicine, Federal University of Rio Grande, Rio Grande, Brazil \\ ${ }^{2}$ Postgraduate Program in Health Sciences, Faculty of Medicine, Federal University of Rio Grande, Rio Grande, Brazil \\ Email: ^leschein@mikrus.com.br, juraci.a.cesar@gmail.com, medicina@furg.br
}

How to cite this paper: Schein, L.E.C. and Cesar, J.A. (2020) Practice Patterns and Adequacy of Maintenance Hemodialysis in Rio Grande, RS, Brazil. Open Journal of Nephrology, 10, 102-116.

https://doi.org/10.4236/ojneph.2020.102011

Received: April 6, 2020

Accepted: May 10, 2020

Published: May 13, 2020

Copyright $\odot 2020$ by author(s) and Scientific Research Publishing Inc. This work is licensed under the Creative Commons Attribution International License (CC BY 4.0).

http://creativecommons.org/licenses/by/4.0/

\begin{abstract}
Introduction: Hemodialysis is the most common end-stage renal disease treatment worldwide. Several factors may influence treatment outcomes. Adequacy (dose) of hemodialysis remains controversial; however, investigations on the effectiveness rate $(\mathrm{Kt} / \mathrm{V} \geq 1.2)$, which could reflect morbimortality, are preferred. Objective: This study aimed to describe the level of adequacy of hemodialysis among patients undergoing treatment in the city of Rio Grande (RS), Brazil. Method: In this prospective cohort study, 156 patients undergoing hemodialysis treatment between July 2016 and June 2017 in the two hemodialysis centers in the city of Rio Grande (RS), Brazil, were included. Frequency distribution as per Kt/V stratification was analyzed. Chi-square test was used to compare proportions. Results: Adequate hemodialysis $(\mathrm{Kt} / \mathrm{V} \geq 1.2)$ was observed in 105 patients $(67 \%), 88 \%$ were from the municipality (mean age, 59 years), and $43 \%$ had visited the hospital before knowing about their kidney disease. Most of them were referred to a nephrologist (70\%). Of the 156 patients, 114 patients (73\%) remained in dialysis treatment, $10(6 \%)$ underwent transplantation, $9(6 \%)$ were transferred, and 23 (15\%) died at the end of 12 months. Conclusion: Primary care should be expanded for early diagnosis of chronic kidney disease, improved venous access preparation, and increased number of patients with hemodialysis adequacy. Hemodialysis adequacy in patients undergoing treatment in the city of Rio Grande (RS), Brazil, needs to be improved.
\end{abstract}

\section{Keywords}

Chronic Kidney Failure, Hemodialysis, Quality Control, Hemodialysis Adequacy, Arteriovenous Fistula

\section{Introduction}

Hemodialysis has resulted in a change in the life expectancy of patients with 
end-stage renal disease (ESRD) since it was first introduced in 1943 [1], and it is considered the most prevalent kidney replacement therapy worldwide. In Brazil, $80 \%$ of more than 122,000 patients are receiving hemodialysis, and the number of visits has increased by $25 \%$ in the last 4 years [2]. With its high cost (over $\$ 700$ million/year) and annual growth, renal replacement therapy could be further improved and treatment adequacy criteria developed [3].

Adequate dialysis refers to the ideal amount of treatment and is related to better health status, longer life expectancy, and lower mortality rate [4] [5]. The Brazilian Nephrology Society and the National Kidney Foundation have developed a standardized linear equation with reliable results for the evaluation of the effectiveness of hemodialysis when performed three times a week [6]. Kt/V is a marker of the effectiveness of hemodialysis. A Kt/V target of 1.4 per hemodialysis session is recommended for patients treated three times a week, with a minimum $\mathrm{Kt} / \mathrm{V}$ of 1.2. Several studies have shown that $\mathrm{Kt} / \mathrm{V} \geq 1.2$ and urea removal rate (URR) $>65 \%$ may improve the prognosis in patients with chronic hemodialysis, thereby indicating sufficient dialysis [7] [8].

The appropriate standard dose of hemodialysis is estimated and fixed by the National Kidney Foundation Kidney Disease Outcomes Quality Initiative (NKF/KDOQI) guidelines, which recommends maintaining a single pool Kt/V (spKt/V) above 1.2, which can and should be measured [9]. Moreover, low Kt/V is associated with high mortality; thus, proper adjustment could improve the survival of hemodialysis patients [5] [10]. Kt/V is universally used as a measure of dialysis treatment intensity, and the ESRD Quality Incentive Program of the US Centers for Medicare \& Medicaid Services includes Kt/V as a comprehensive clinical measure of dialysis adequacy [4].

Maintenance hemodialysis, which is established after the admission of a patient with ESRD in a continuous dialysis program, is prescribed based on medical indication and clinical evaluation of a nephrologist. In Brazil, the Brazilian Chronic Dialysis Inquiry in 2016 received data from $41 \%$ of the 747 hemodialysis units (approximately 50,000 patients), which showed that $21 \%$ had inadequate $\mathrm{Kt} / \mathrm{V}(<1.2)$ and revealed a stable mortality rate of approximately $18 \%$ [11]. Numerous studies showed a high number of deaths and hospitalizations associated with inadequate $\mathrm{Kt} / \mathrm{V}$, anemia, low albumin, and use of vascular access other than arteriovenous fistula (AVF) [12] [13]. Patients who are evaluated by a nephrologist up to 4 months before dialysis were classified as late referral; those evaluated 4 to 12 months and $>12$ months before dialysis, as intermediate and early referral, respectively [14].

This study was conducted to describe the adequacy of hemodialysis in patients under maintenance treatment in the city of Rio Grande, Brazil, between July 2016 and June 2017. Other criteria of good adequacy were observed, including early referral (referral to the nephrologist at least 12 months before hemodialysis), planned dialysis, presence of arteriovenous fistula, and no hospitalizations during the study period [15]. 


\section{Materials and Methods}

The municipality of Rio Grande is located in Southern Brazil. It has about 210,000 inhabitants and is one of the 10 most populous cities of the state of Rio Grande do Sul. The municipal human development index reached 0.744 in 2010. The city built its history in port and oil refining activities. It harbors the headquarters of the Federal University of Rio Grande (FURG), with approximately 11,000 students. It has a public university hospital and a nonprofit hospital, with a total of $>600$ hospital beds; 32 primary health care facilities, of which 19 have family health staff [16]; and two hemodialysis centers that could assist to $150 \mathrm{pa}-$ tients regularly.

All patients in a regular chronic hemodialysis program between July 2016 and June 2017, who were admitted to the hemodialysis program for at least 4 weeks, and with the first dose of $\mathrm{Kt} / \mathrm{V}$ performed after 30 days of treatment were included in this prospective cohort study. Of these, one refused to participate and three had not performed examinations in the appropriate protocol, totaling 156 fit individuals. Inclusion criteria were being admitted to the hemodialysis program, agreeing to participate, and providing informed consent. Patients with acute renal failure or hemodialysis in an intensive care unit were excluded. The participants were evaluated at baseline and at 6 and 12 months.

Data were obtained using a pre-coded standard questionnaire that sought information on demographic characteristics (origin, age, schooling, household income), access to hemodialysis (referral, conservative treatment time, type of venous access used), side effects (pain complaints, hemoglobin level, parathyroid hormone (PTH), Kt/V, URR), and reason for leaving the program (transplantation, transfer, or death). Moreover, the study population had regular hemodialysis for 12 months, with three weekly sessions (mean duration, $3.1 \pm(0.4) \mathrm{h}$ ); the same dialysis machine was used and polyethersulfone membrane (service I) or polypropylene (service II) were employed. During hemodialysis, blood flow ranged from 300 to $350 \mathrm{ml} / \mathrm{min}$, while the dialysate flow was at $500 \mathrm{ml} / \mathrm{min}$; reverse osmosis was used for water treatment [6] [12]. Kt/V (fractional urea clearance) and URR calibrators were used to calculate the effectiveness and suitability of hemodialysis. For Kt/V, only values $\geq 1.2$ indicate an effective result. URR was obtained by the ratio between pre- and post-hemodialysis plasma urea, with a minimum value of $65 \%$ [17]. This study was approved by the Research Ethics Committee (CEPAS) of the FURG (no. 23.116.007919/2016-06 CAAE: 60651316.6.0000.5324.)

\section{Statistical analysis}

Independent, experienced interviewers performed the data collection. They visited one of the centers daily, conducted interviews, coded the questions, and entered data in the EpiData 3.1 program (www.epidata.dk). Thereafter, the statistical package Stata 14 (StataCorp. 2015. Stata Statistical Software: Release 14. College Station, TX: StataCorp LP) was used to analyze for consistency, finalize the data, and categorize and create derived variables. Statistical analysis con- 
sisted of frequency verification, which is shown in absolute and relative values, and calculations of measures of central tendency and dispersion, when applicable. Proportions were compared using the chi-square test. The level of significance used for all analyses was 0.05 .

\section{Results and Discussion}

At baseline, all the 156 patients admitted to this study were stratified by hemodialysis adequacy rate $(\mathrm{Kt} / \mathrm{V})$, separated into two groups (i.e., adequate $(\geq 1.2)$ and inadequate $(<1.2)$ dose groups), and interviewed again at 6 and 12 months of continuous treatment. The dialysis adequacy observed in the patients ranged from 0.4 (minimum) to 2.1 (maximum) of dialysis adequacy units. Of the total number of patients who met inclusion criteria for the study, 33\% did not reach the appropriate $\mathrm{Kt} / \mathrm{V}$.

Baseline demographic and socioeconomic characteristics and access to treatment are summarized in Table 1. Almost all respondents (88\%) were from the municipality (aged between 16 and 89 years; mean age, $58 \pm 14$ years). No difference in the adequacy prevalence rates between sexes was observed; however, treatment inadequacy was significantly $(18 \%)$ lower in women $(\mathrm{p}=0.001)$.

Most of the patients were white (79\%), and $36 \%$ had up to 4 years of schooling, 59\% had a monthly household income of <US\$ 750 (equivalent to about three minimum wages in Brazil), and $40 \%$ were economically active. One third of the patients had a health plan, and the most prevalent diseases were diabetes (38\%) and hypertension (81\%). Before starting hemodialysis, $40 \%$ of the patients were engaged in physical activity, which reduced to $10 \%$ when the treatment started, all without significant differences when applying adequacy criteria.

Before being diagnosed with renal disease, $43 \%$ of the patients reported visits to the hospital, and most of the patients were referred to a nephrologist (69\%); however, few (23\%) continued to be monitored. Conservative treatment for $>12$ months was performed in $<20 \%$ of the sample.

The first hemodialysis was unplanned in $57 \%$ of the patients. Most patients (89\%) underwent hemodialysis with access through a central venous catheter (CVC), and only $11 \%$ had an arteriovenous fistula (AVF). At admission (baseline), almost all patients (90\%) who started hemodialysis with an AVF had adequate $\mathrm{Kt} / \mathrm{V}$ rates $(\mathrm{p}<0.004) . \mathrm{Kt} / \mathrm{V}$ was adequate in $56 \%$ of those with AVF who were evaluated at the time of the interview $(50 \%)(\mathrm{p}=0.03)$.

In Table 2 , the prevalence of adequate levels $(\mathrm{Kt} / \mathrm{V} \geq 1.2)$ was higher in patients with $>12$ months of treatment than in those with a shorter treatment time $(\mathrm{p}=0.03)$. When asked about behavior during the last 30 days of hemodialysis, they were generally feeling well $(60 \%)$ and recovered the condition expected less than 1 hour after the session (67\%). The most frequently reported complaints were muscle pain (30\%), hypotension (56\%), cramps (48\%), vomiting (30\%), pruritus (40\%), and restless legs (40\%), which showed no different between the two groups of Kt/V index. No difference in the frequency of hospitalization (43\%) in the last 12 months after treatment onset between groups was found. 
Table 1. Distribution of patients by adequacy of treatment performed and the main characteristics investigated (Rio Grande, RS, July 2016-June 2017).

\begin{tabular}{|c|c|c|c|c|}
\hline \multirow{3}{*}{ Variables } & \multicolumn{2}{|c|}{ Hemodialysis adequacy } & \multirow{3}{*}{$\begin{array}{l}\text { Total } \\
\text { n (\%) }\end{array}$} & \multirow{3}{*}{$\mathrm{p}$ value } \\
\hline & No & Yes & & \\
\hline & $\begin{array}{c}\mathrm{Kt} / \mathrm{V}<1.2 \\
\mathrm{n}(\%)\end{array}$ & $\begin{array}{c}\mathrm{Kt} / \mathrm{V} \geq 1.2 \\
\mathrm{n}(\%)\end{array}$ & & \\
\hline Place of residence & & & & 0.912 \\
\hline Rio Grande & $45(88)$ & $92(88)$ & $137(88)$ & \\
\hline Age (years) & & & & 0.458 \\
\hline$\geq 60$ & $28(55)$ & $51(49)$ & $79(51)$ & \\
\hline Sex & & & & 0.001 \\
\hline Male & $42(82)$ & $46(44)$ & $88(56)$ & \\
\hline Female & $9(18)$ & $59(56)$ & $68(44)$ & \\
\hline Skin color (self-reported) & & & & 0.942 \\
\hline White & $41(80)$ & $83(79)$ & $124(79)$ & \\
\hline Brown & $6(12)$ & $12(11)$ & $18(12)$ & \\
\hline Black & $4(8)$ & $10(10)$ & $14(9)$ & \\
\hline Schooling (years) & & & & 0.388 \\
\hline 0 to 4 & $21(41)$ & $36(34)$ & $57(36)$ & \\
\hline 5 to 8 & $18(35)$ & $33(32)$ & $51(33)$ & \\
\hline$\geq 9$ & $12(24)$ & $36(34)$ & $48(31)$ & \\
\hline $\begin{array}{l}\text { Monthly household income } \\
\text { (in minimum wages) }\end{array}$ & & & & 0.104 \\
\hline$\leq 1.9$ & $5(10)$ & $27(26)$ & $32(20)$ & \\
\hline 2.0 to 2.9 & $20(39)$ & $40(38)$ & $60(39)$ & \\
\hline 3.0 to 3.9 & $10(20)$ & $16(15)$ & $26(17)$ & \\
\hline$\geq 4.0$ & $16(31)$ & $22(21)$ & $38(24)$ & \\
\hline Occupation before hemodialysis & & & & 0.244 \\
\hline Working and earning & $25(49)$ & $37(35)$ & $62(40)$ & \\
\hline Before hemodialysis & & & & 0.984 \\
\hline Engaged in physical activity & $20(39)$ & $41(39)$ & $61(39)$ & \\
\hline After onset of hemodialysis & & & & 0.489 \\
\hline Engaged in physical activity & $4(8)$ & $12(11)$ & $16(10)$ & \\
\hline Has health plan & $15(29)$ & $37(35)$ & $52(33)$ & 0.469 \\
\hline Hypertensive & $38(75)$ & $88(84)$ & $126(81)$ & 0.167 \\
\hline Has diabetes mellitus & $24(47)$ & $35(33)$ & $59(38)$ & 0.100 \\
\hline Total & $51(33)$ & $105(67)$ & $156(100)$ & \\
\hline
\end{tabular}




\begin{tabular}{|c|c|c|c|c|}
\hline \multirow{3}{*}{ Variables } & \multicolumn{2}{|c|}{ Hemodialysis adequacy } & \multirow{3}{*}{$\begin{array}{l}\text { Total } \\
\text { n (\%) }\end{array}$} & \multirow{3}{*}{$\mathrm{p}$ value } \\
\hline & No & Yes & & \\
\hline & $\begin{array}{c}\mathrm{Kt} / \mathrm{V}<1.2 \\
\mathrm{n}(\%)\end{array}$ & $\begin{array}{c}\mathrm{Kt} / \mathrm{V} \geq 1.2 \\
\mathrm{n}(\%)\end{array}$ & & \\
\hline Medical visits before CKD & $18(35)$ & $49(47)$ & $67(43)$ & 0.178 \\
\hline Referred to the nephrologist & $35(69)$ & $73(70)$ & $108(69)$ & 0.909 \\
\hline Conservative treatment with nephrologist & $11(22)$ & $26(25)$ & $37(24)$ & 0.131 \\
\hline Time under conservative treatment & & & & 0.334 \\
\hline Up to 11.9 months & $3(6)$ & $7(7)$ & $10(6)$ & \\
\hline$\geq 12$ months & $8(16)$ & $21(20)$ & $29(19)$ & \\
\hline Does not remember & $1(2)$ & $9(9)$ & $10(6)$ & \\
\hline \multirow[t]{2}{*}{ Immediate dialysis } & $39(77)$ & $68(65)$ & $107(69)$ & \\
\hline & $23(45)$ & $45(43)$ & $68(43)$ & 0.791 \\
\hline First hemodialysis & & & & 0.04 \\
\hline By catheter & $49(96)$ & $89(85)$ & $138(89)$ & \\
\hline By arteriovenous fistula & $2(4)$ & $16(15)$ & $18(11)$ & \\
\hline Current access route & & & & 0.03 \\
\hline Arteriovenous fistula & $19(37)$ & $59(56)$ & $78(50)$ & \\
\hline Total & $51(33)$ & $105(67)$ & $156(100)$ & \\
\hline
\end{tabular}

CKD, chronic kidney disease.

Table 2. Treatment standard and adequacy of hemodialysis (Rio Grande, RS. July 2016-June 2017.

\begin{tabular}{|c|c|c|c|c|}
\hline \multirow{3}{*}{ Variables } & \multicolumn{2}{|c|}{ Hemodialysis adequacy } & \multirow{3}{*}{$\begin{array}{l}\text { Total } \\
\mathrm{n}(\%)\end{array}$} & \multirow{3}{*}{$\mathrm{p}$ value } \\
\hline & \multirow{2}{*}{$\begin{array}{c}\text { No } \\
\mathrm{Kt} / \mathrm{V}<1.2 \\
\mathrm{n}(\%)\end{array}$} & \multirow{2}{*}{$\begin{array}{c}\text { Yes } \\
\mathrm{Kt} / \mathrm{V} \geq 1.2 \\
\mathrm{n}(\%)\end{array}$} & & \\
\hline & & & & \\
\hline Time in hemodialysis & & & & 0.028 \\
\hline$<1$ year & $32(63)$ & $42(40)$ & $74(47)$ & \\
\hline$\geq 1$ to 4.9 years & $13(25)$ & $43(41)$ & $56(36)$ & \\
\hline$\geq 5$ years & $6(12)$ & $20(19)$ & $26(17)$ & \\
\hline $\begin{array}{l}\text { In high spirits in the last } 30 \text { days } \\
\text { after hemodialysis }\end{array}$ & $30(59)$ & $68(65)$ & $98(63)$ & 0.472 \\
\hline $\begin{array}{l}\text { Required assistance in the last } 30 \text { day } \\
\text { after hemodialysis }\end{array}$ & $8(16)$ & $15(14)$ & $23(15)$ & 0.942 \\
\hline $\begin{array}{c}\text { Recovered in }<1 \mathrm{~h} \text { in the last } 30 \text { days } \\
\text { after hemodialysis }\end{array}$ & $37(73)$ & $67(64)$ & $104(67)$ & 0.534 \\
\hline \multicolumn{5}{|l|}{$\begin{array}{l}\text { Complaints after hemodialysis } \\
\text { session in the last } 30 \text { days }\end{array}$} \\
\hline Muscular pain & $16(31)$ & $30(29)$ & $46(30)$ & 0.719 \\
\hline Hypotension & $30(59)$ & $58(56)$ & $88(56)$ & 0.672 \\
\hline
\end{tabular}




\section{Continued}

\begin{tabular}{|c|c|c|c|c|}
\hline Hypertension & $22(43)$ & $52(50)$ & $74(47)$ & 0.454 \\
\hline Cramps & $26(51)$ & $49(47)$ & $75(48)$ & 0.613 \\
\hline Restless legs & $23(46)$ & $42(40)$ & $65(42)$ & 0.545 \\
\hline Nausea vomiting & $15(29)$ & $30(29)$ & $45(29)$ & 0.913 \\
\hline Headache & $13(26)$ & $41(39)$ & $54(35)$ & 0.095 \\
\hline Chest pain & $13(26)$ & $17(16)$ & $30(19)$ & 0.312 \\
\hline Pruritus & $17(33)$ & $45(43)$ & $62(40)$ & 0.254 \\
\hline Hospitalized any time after hemodialysis & $20(39)$ & $47(45)$ & $67(43)$ & 0.512 \\
\hline Total & $51(33)$ & $105(67)$ & \multicolumn{2}{|l|}{$156(100)$} \\
\hline \multirow{3}{*}{ Variables } & \multicolumn{2}{|c|}{ Hemodialysis adequacy } & \multirow{3}{*}{$\begin{array}{l}\text { Total } \\
\mathrm{n}(\%)\end{array}$} & \multirow{3}{*}{$\mathrm{p}$ value } \\
\hline & \multirow{2}{*}{\multicolumn{2}{|c|}{$\begin{array}{cc}\text { No } & \text { Yes } \\
\mathrm{Ktv}<1.2 & \mathrm{Ktv} \geq 1.2 \\
\mathrm{n}(\%) & \mathrm{n}(\%)\end{array}$}} & & \\
\hline & & & & \\
\hline Baseline hemoglobin & & & & 0.776 \\
\hline$\geq 11.0 \mathrm{~g} \%$ & $14(28)$ & $33(32)$ & $47(31)$ & \\
\hline Baseline ferritin & & & & 0.638 \\
\hline High ( $\geq 500$ ng/mL) & $3(6)$ & $11(11)$ & $14(9)$ & \\
\hline PTH $(n=155)$ & & & & 0.987 \\
\hline High $(\geq 300$ pg/ml) & $23(46)$ & $48(46)$ & $71(46)$ & \\
\hline $\mathrm{Ca} / \mathrm{P}$ product $(\mathrm{n}=154)$ & & & & 0.902 \\
\hline High $\left(\geq 55.0 \mathrm{mg}^{2} / \mathrm{dl}^{2}\right)$ & $14(29)$ & $29(28)$ & $43(28)$ & \\
\hline Total calcium & & & & 0.769 \\
\hline$<8.8 \mathrm{mg} \%$ (low) & $13(26)$ & $28(27)$ & $41(26)$ & \\
\hline $8.8 \mathrm{mg} \%-10.2 \mathrm{mg} \%$ (normal) & $38(74)$ & $76(72)$ & $114(73)$ & \\
\hline$>8.8$ mg\% (high) & - & $1(1)$ & $1(1)$ & \\
\hline Serum phosphorus & & & & 0.963 \\
\hline$\geq 5.5 \mathrm{mEq} / 1$ & $24(47)$ & $49(47)$ & $73(47)$ & \\
\hline Serum potassium & & & & 0.195 \\
\hline$\geq 5.5 \mathrm{mEq} / 1$ & $14(27)$ & $41(39)$ & $55(35)$ & \\
\hline Urea reduction rate & & & & 0.000 \\
\hline$>65 \%$ (adequate) & $2(4)$ & $87(83)$ & $89(57)$ & \\
\hline Baseline albumin $(\mathrm{n}=90)$ & & & & 0.343 \\
\hline$\geq 3.5 \mathrm{~g} \%$ & $22(82)$ & $56(89)$ & $78(87)$ & \\
\hline Patient development & & & & 0.465 \\
\hline Under treatment & $36(71)$ & $78(74)$ & $114(73)$ & \\
\hline Transferred & $3(6)$ & $6(6)$ & $9(6)$ & \\
\hline Transplanted & $6(11)$ & $4(4)$ & $10(6)$ & \\
\hline Death & $6(12)$ & $17(16)$ & $23(15)$ & \\
\hline Total & $51(33)$ & $105(67)$ & $156(100)$ & \\
\hline
\end{tabular}

PTH, Parathyroid hormone; Ca/P, Calcium phosphorus. 
Hemoglobin > $11 \mathrm{~g} \%$ (30\%), serum calcium between $8.8 \mathrm{mg} \%$ and $10.2 \mathrm{mg} \%$ (70\%), and albumin $>3.5 \mathrm{~g} \%(87 \%)$, which are considered good treatment targets, were observed; no difference between the groups was found. Results higher than expected, such as ferritin (10\%), PTH (45\%), calcium/phosphorus product (30\%), plasma phosphorus (47\%), and potassium (35\%), were also not different between the groups studied.

Table 3 shows that adequacy rate, which is measured by Kt/V, started at $67 \%$ at baseline, which decreased to $60 \%$ after 6 months and $51 \%$ at the end of 12 months. The URR, measuring the same parameter, did not change. Patients aged $\geq 60$ years and those with a hemoglobin level $>11 \mathrm{~g} \%$ showed no differences in any the results of the evaluations performed. In all three evaluations, females consistently had significantly higher rates than males $(\mathrm{p}<0.01)$.

During the follow-up, 114 patients (73\%) remained in dialysis treatment after 12 months, $6 \%$ were transferred for treatment in another municipality, $6 \%$ had transplantation, and 23 (15\%) died; however, no significant difference between those with and those without treatment adequacy was found.

Numerous studies have shown the link between dialysis adequacy and morbimortality [4] [6]. In our study, of the 156 patients, $67 \%$ had adequate $\mathrm{Kt} / \mathrm{V} \geq$ 1.2. At the end of 12 months of treatment, the number of adequately dialyzed patients declined to $51 \%$. Moreover, a large number of patients had not sought

Table 3. Behavior and treatment adequacy assessment among patients on chronic hemodialysis at baseline and at 6 and 12 months (Rio Grande, RS. July 2016-June 2017). Efficient matching if Kt/V $\geq 1.2$.

\begin{tabular}{|c|c|c|c|c|c|c|c|c|c|c|c|c|}
\hline & \multirow{2}{*}{\multicolumn{2}{|c|}{$\begin{array}{c}\text { Baseline } \\
\text { Adequacy index }\end{array}$}} & \multirow{4}{*}{$\begin{array}{l}\text { Total } \\
\mathrm{n}(\%)\end{array}$} & \multirow{4}{*}{$\mathrm{p}$ value } & \multirow{2}{*}{\multicolumn{2}{|c|}{$\begin{array}{c}6 \text { months } \\
\text { Adequacy index }\end{array}$}} & \multirow{4}{*}{$\begin{array}{l}\text { Total } \\
\text { n (\%) }\end{array}$} & \multirow{4}{*}{$\mathrm{p}$ value } & \multirow{2}{*}{\multicolumn{2}{|c|}{$\begin{array}{c}12 \text { months } \\
\text { Adequacy index }\end{array}$}} & \multirow{4}{*}{$\begin{array}{l}\text { Total } \\
\text { n (\%) }\end{array}$} & \multirow{4}{*}{$p$ value } \\
\hline & & & & & & & & & & & & \\
\hline & \multicolumn{2}{|c|}{$\mathrm{Ktv}<1.2 \mathrm{Ktv} \geq 1.2$} & & & $\mathrm{Ktv}<1.2$ & $\mathrm{Ktv} \geq 1.2$ & & & $\mathrm{Ktv}<1.2$ & $\mathrm{Ktv} \geq 1.2$ & & \\
\hline & n (\%) & n (\%) & & & n (\%) & n (\%) & & & n (\%) & n (\%) & & \\
\hline Gender & & & & $<0.000$ & & & & 0.013 & & & & 0.004 \\
\hline Male & $42(82)$ & $46(44)$ & $88(56)$ & & $30(71)$ & $30(47)$ & $60(57)$ & & $23(72)$ & $12(36)$ & $35(54)$ & \\
\hline Female & $9(18)$ & $59(56)$ & $68(44)$ & & $12(29)$ & $34(53)$ & $46(43)$ & & $9(28)$ & $21(64)$ & $30(46)$ & \\
\hline Age & & & & 0.458 & & & & 0.810 & & & & 0.265 \\
\hline$\geq 60$ years & $28(55)$ & $51(49)$ & $79(51)$ & & $20(48)$ & $32(50)$ & $52(49)$ & & $18(56)$ & $14(42)$ & $32(49)$ & \\
\hline Hemoglobin & & & & 0.776 & & & & 0.351 & & & & 0.127 \\
\hline$(\geq 11 \mathrm{~g} \%)$ & $14(28)$ & $33(32)$ & $47(31)$ & & $24(57)$ & $28(44)$ & $52(49)$ & & $11(34)$ & $10(30)$ & $21(32)$ & \\
\hline $\begin{array}{l}\text { Time under } \\
\text { hemodialysis }\end{array}$ & & & & 0.028 & & & & 0.232 & & & & 0.773 \\
\hline$<1$ year & $32(63)$ & $42(40)$ & $74(47)$ & & $16(38)$ & $31(48)$ & $47(44)$ & & $9(28)$ & $7(21)$ & $16(25)$ & \\
\hline 1 year to $<5$ years & $13(25)$ & $43(41)$ & $56(36)$ & & $20(48)$ & $20(31)$ & $40(38)$ & & $16(50)$ & $17(52)$ & $33(50)$ & \\
\hline$>5$ years & $6(12)$ & $20(19)$ & $26(17)$ & & $6(14)$ & $13(20)$ & $19(18)$ & & $7(22)$ & $9(27)$ & $16(25)$ & \\
\hline Urea reduction rate & & & & 0.043 & & & & $<0.000$ & & & & $<0.000$ \\
\hline$>65 \%$ (adequate) & $2(4)$ & $87(83)$ & $89(57)$ & & $1(2)$ & $53(83)$ & $54(51)$ & & $5(16)$ & $31(94)$ & $36(53)$ & \\
\hline Total & $51(33)$ & $105(67)$ & $156(100)$ & & $42(40)$ & $64(60)$ & $106(100)$ & & $32(49)$ & $33(51)$ & $65(100)$ & \\
\hline
\end{tabular}


medical care until they were diagnosed with a kidney disease (57\%). Most of the patients were referred to (69\%) but few were followed up by nephrologists (23\%). Less than one third had conservative treatment (31\%), while the others started hemodialysis immediately, which indicates that most patients (69\%) had a late referral. Thus, most of the patients were already in an advanced stage of renal disease at the initial visit, thereby increasing the morbimortality rate during treatment [18].

We described the hemodialysis adequacy achieved by $67 \%$ of the patients concerning socioeconomic, clinical, and behavioral factors. The limits applied in Brazil and in this study, i.e., a minimum Kt/V of 1.2 and URR $>65 \%$, were the same as those used by guidelines in the USA, UK, Canada, and Spain. URR was calculated by dividing the difference between BUNpre and BUNpost by BUNpre (using the same BUN values used to calculate Kt/V) [19]. In our study, regarding the adequacy achieved and measured by the $\mathrm{Kt} / \mathrm{V}$ index, declining adequacy scores were found at 12 months. Of the 156 patients admitted at baseline, 105 (67\%) had adequate $\mathrm{Kt} / \mathrm{V}$, and of the remaining 106 patients at 6 months, 64 (60\%) had adequate $\mathrm{Kt} / \mathrm{V}$. A total of 65 patients completed the 12 months of follow-up, and only $51 \%$ maintained adequate $\mathrm{Kt} / \mathrm{V}$ levels. This decline could be attributed to several factors: problems with access (catheter) or lack of AVF; failure to maintain the expected flow in all sessions; intercurrences during the session, preventing regularity in the dialysis time; and deteriorated general condition of the patient. All of these factors could result in a lower effective treatment time and, thus, loss of adequacy rates. Although described in the literature, these parameters were not explored in this study; thus, this is one of the limitations of our study. Furthermore, a review of hemodialysis adequacy among Japanese patients found excellent treatment rates. For example, only $18 \%$ of dialyzed patients in Tokyo in 2014 had inadequate rates $(\mathrm{Kt} / \mathrm{V}<1.2)$. The prevalence of inadequate hemodialysis was $26 \%$ in Italy, $28 \%$ in China, and $42 \%$ in Serbia. In Egypt, up to $60 \%$ of hemodialysis insufficiency was reported [20] [21] [22].

Some observational studies consistently showed improved survival at appropriate hemodialysis doses, thereby encouraging all services to focus on achieving adequate Kt/V levels [22] [23]. Randomized clinical trials, as well as the Dialysis Outcomes and Practice Patterns Study, have shown that increasing Kt/V above the standard does not improve outcomes [24]. Hence, high Kt/V level does not always increase the survival rate [17]. Our results showed that the mortality rate was $15 \%$ during the 12 months of evaluation, with no significant difference between the groups with and without treatment adequacy.

The arteriovenous fistula, which is a factor significantly associated with adequacy, is the preferred access for hemodialysis. It reduces mortality, hospitalizations, and costs and improves survival [25] [26]. However, a Brazilian review with 2276 patients published in 2011 found that $30 \%$ of the patients started dialysis with an AVF [27]. In developed countries such as the US, only $20 \%$ of the patients start hemodialysis with an AVF [28]. El-Sheikh highlighted that hemo- 
dialysis adequacy is affected by several factors; among these factors, having a functioning vascular access provides better treatment results [21]. Studies conducted in Brazil and Canada showed that patients who use AVF have better dialysis adequacy than those with CVC [29] [30]. In 2015, the National UK Renal Registry reported that $40 \%$ of English people started hemodialysis with AVF. In Japan, in $2014,>75 \%$ of the patients had an AVF before the onset of hemodialysis, and in chronic hemodialysis, $90 \%$ used AVF [31]. Most of the patients in the aforementioned studies and in the study performed at the Hospital de Clinicas in São Paulo in 2015 had no vascular access for their first hemodialysis (89.4\%) [32].

In Rio Grande, $57 \%$ of the patients started dialysis urgently and without preparation. The venous access in the first hemodialysis in most of the patients (89\%) was through a CVC, which could increase morbimortality [33]. Only $11 \%$ had an AVF already in place, suggesting that conservative pre-dialysis treatment may have been rare in this population, which in turn could explain the low adequacy rates found for both the urgency of the onset and the lack of adequate access such as the AVF. Thus, based on the literature and on our findings, hemodialysis adequacy is significantly predominant in patients with an AVF $(\mathrm{p}=0.04)$ and in those with a functioning fistula in maintenance hemodialysis $(p=0.03)$ [34].

Mean age of the patients in Rio Grande was 58 years, which was lower than that of the patients in Spain and Japan (69 and 65 years, respectively). This could be because the aging population in developed countries has increased, which could be attributed to the increased survival in chronic renal disease and the greater hemodialysis adequacy rates [18] [35].

A previous study showed that women had better hemodialysis adequacy than men [36]. Our data showed adequate dialysis in $87 \%$ of women and $52 \%$ of men at baseline $(\mathrm{p}=0.0001)$. At 6 and 12 months, adequacy in women remained higher than that in men $(\mathrm{p}=0.004)$. This difference may be due to several factors, such as hormonal variation and smaller muscular mass, smoking and alcohol cessation, and adherence to a healthier diet [36]. Possible biases to be considered also in this population, and which could explain why women may have obtained better results than men, is observed in the Hemodialysis Study (HEMO), where the highest dose (kt/V) would be result of the use of " $\mathrm{V}$ " as a normalizing factor, since women have a lower anthropometric $\mathrm{V}$ per unit surface area (V/SA) than man [37].

The frequency of complaints, such as muscle pain, hypotension, cramps, pruritus, and restless legs, and frequency of hospitalization (43\%) in the last 12 months did not show significant differences between the groups after treatment onset. Patients on chronic hemodialysis and with a hemoglobin level $\geq 11 \mathrm{~g} \%$, which account for $30 \%$ of the study population, have a higher risk of adverse events, hospitalizations, and mortality [38]; however, a comparison with the other patients revealed no difference in treatment adequacy. Moreover, a 15\% mortality rate was found among the 156 patients in this study, which is similar to that of national studies conducted in Minas Gerais (14\%) and Maranhão 
(15\%) [39]. Data from the US Renal Data System showed that the overall hemodialysis mortality in the USA decreased from $25 \%$ to $<20 \%$ in 2012 and was $<10 \%$ in Japan in the first year of treatment [22] [28] [35].

The limiting factor of this study, which was also highlighted in recent studies, is that dialysis adequacy involves a parameter $(\mathrm{Kt} / \mathrm{V})$ to be met and does not translate into treatment efficiency. Another factor was the reduction in the cohort over 12 months, i.e., from 156 (baseline) to 65 patients. Other relevant limitations include the high number of CVC use, which may have delayed AVF use, and the urgent need to initiate hemodialysis. Thus, one should dispel the impression that dialysis adequacy is sufficient and that the purpose of the treatment has been achieved [24].

\section{Conclusions}

We observed that $67 \%$ of the 156 admitted patients had effective $\mathrm{Kt} / \mathrm{V}$ values $(>1.2)$ at the first assessment. Over the next 12 months, only 51\% maintained effectiveness levels, which shows a reduction in expected values of treatment adequacy.

Based on the findings of this study, hemodialysis adequacy in Rio Grande remains far from that in developed countries. Thus, increasing hemodialysis adequacy, with a reduced percentage of patients who do not reach or maintain the $\mathrm{Kt} / \mathrm{V}$ target, remains an objective of treatment.

Conservative treatment over 12 months and with nephrologist follow-up was performed in only $20 \%$ of the patients studied, making clear the need to expand and facilitate CKD patients' access to specialized care. Most patients (69\%) received late referral for hemodialysis.

Also noteworthy is the significant use of central venous catheters in the initial access (89\%), as well as the low frequency of AVF (11\%), two of the factors that may change and contribute to improved hemodialysis adequacy, better quality of life, efficacy of treatment, and reduction of morbidity and mortality.

Moreover, the presence of AVF at the treatment onset or AVF implanted during the treatment showed a positive effect on obtaining hemodialysis adequacy. Our findings indicate that measures to promote and expand the use of fistulas before starting treatment are warranted.

Furthermore, attention should also be directed to the high percentage of patients who had emergency hemodialysis (57\%) and the male predominance in treatment inadequacy. Our findings could be used in future studies to further show the importance of achieving and maintaining hemodialysis adequacy, streamlining conservative treatment, and using AVF.

\section{Acknowledgements}

This article is part of the doctoral thesis titled: "Patients in chronic hemodialysis: therapeutic itinerary and treatment adequacy", defended in August 2018. We are grateful to the Graduate Program in Health Sciences of the Federal University of 
Rio Grande RS, FURG (Brazil), Hospital Santa Casa do Rio Grande and the Hemodialysis Clinic of Rio Grande RS, for the availability of the research in its hemodialysis centers.

\section{Data Availability}

The datasets used and/or analyzed during the current study are available from the corresponding author.

\section{Supported}

The work was financially supported solely by the authors.

\section{Conflicts of Interest}

Regarding the ethical imperative about possible factors that influence the results of the research, we point out that there are no conflicts of interest, professional, financial and direct or indirect benefits of such linkages.

\section{References}

[1] Kolff, W.J., Berk, H.T., ter Welle, M., van der Ley, A.J., van Dijk, E.C. and van Noordwijk, J. (1997) The Artificial Kidney: A Dialyser with a Great Area. 1944. Journal of the American Society of Nephrology, 8, 1959-1965.

[2] de Menezes, F.G., Barreto, D.V., Abreu, R.M., Roveda, F. and Pecoits Filho, R.F. (2015) Overview of Hemodialysis Treatment Funded by the Brazilian Unified Health System-An Economic Perspective. Jornal Brasileiro de Nefrologia, 37, 367-378. https://doi.org/10.5935/0101-2800.20150057

[3] Santos, D.R. and Moura, L.R.R. (2014) Dia Mundial do Rim de 2014. Sociedade Brasileira de Nefrologia (SBN). http://arquivos.sbn.org.br/pdf/texto_dmr2_2014.pdf

[4] Perl, J., Dember, L.M., Bargman, J.M., Browne, T., Charytan, D.M., Flythe, J.E., et al. (2017) The Use of a Multidimensional Measure of Dialysis Adequacy-Moving beyond Small Solute Kinetics. The Clinical Journal of the American Society of Nephrology, 12, 839-847. https://doi.org/10.2215/CJN.08460816

[5] Theofilou, P., Togas, C., Vasilopoulou, C., Minos, C., Zyga, S. and Tzitzikos, G. (2015) The Impact of Kt/V Urea-Based Dialysis Adequacy on Quality of Life and Adherence in Haemodialysis Patients: A Cross-Sectional Study in Greece. Health Psychology Research, 3, 1060. https://doi.org/10.4081/hpr.2015.1060

[6] National Kidney Foundation (2015) KDOQI clinical Practice Guideline for Hemodialysis Adequacy: 2015 Update. American Journal of Kidney Diseases, 66, 884-930. https://doi.org/10.1053/j.ajkd.2015.07.015

[7] Borzou, S.R., Gholyaf, M., Zandiha, M., Amini, R., Goodarzi, M.T. and Torkaman, B. (2009) The Effect of Increasing Blood Flow Rate on Dialysis Adequacy in Hemodialysis Patients. Saudi Journal of Kidney Disease and Transplantation, 20, 639-642.

[8] Sumida, K. and Kovesdy, C.P. (2017) Disease Trajectories before ESRD: Implications for Clinical Management. Seminars in Nephrology, 37, 132-143. https://doi.org/10.1016/j.semnephrol.2016.12.003

[9] National Kidney Foundation (2006) KDOQI Clinical Practice Guideline and Clinical Practice Recommendations: Hemodialysis Adequacy, Peritoneal Dialysis Adequacy and Vascular Access: Update 2006. American Journal of Kidney Diseases, 48, 
S1-S322. https://doi.org/10.1053/j.ajkd.2006.03.051

[10] Moss, A.H. (2010) Revised Dialysis Clinical Practice Guideline Promotes More Informed Decision-Making. The Clinical Journal of the American Society of Nephrology, 5, 2380-2383. https://doi.org/10.2215/CJN.07170810

[11] Sesso, R.C., Lopes, A.A., Thomé, F.S., Lugon, J.R. and Martins, C.T. (2017) Brazilian Chronic Dialysis Survey 2016. Jornal Brasileiro de Nefrologia, 39, 261-266. https://doi.org/10.5935/0101-2800.20170049

[12] Grangé, S., Hanoy, M., Le Roy, F., Guerrot, D. and Godin, M. (2013) Monitoring of Hemodialysis Quality-of-Care Indicators: Why Is It Important? BMC Nephrology, 14, 109. https://doi.org/10.1186/1471-2369-14-109

[13] Duarte, P.S., Miyazaki, M.C.O.S., Ciconelli, R.M. and Sesso, R. (2003) Tradução e adaptação cultural do instrumento de avaliação de qualidade de vida para pacientes renais crônicos (KDQOL-SF TM). Revista da Associação Médica Brasileira, 49, 375-381. https://doi.org/10.1590/S0104-42302003000400027

[14] Bersan, S.A., Amaral, C.F., Gomes, I.C. and Cherchiglia, M.L. (2013) Letalidade e internações de pacientes em hemodiálise em plano de saúde. Revista de Saúde Pública, 47, 624-633. https://doi.org/10.1590/S0034-8910.2013047004016

[15] Brenner, B.M., Rector, F.C. and Taal, M.W. (2004) Brenner \& Rector's The Kidney. 7th Edition, Elsevier Saunders, Philadelphia, PA.

[16] Brazilian Ministry of Planning, Budget and Management, Brazilian Institute of Geography and Statistics (2018) IBGE-Brasil em Síntese. https://cidades.ibge.gov.br/brasil/rs/rio-grande/panorama

[17] Masakane, I. (2010) High-Quality Dialysis: A Lesson from the Japanese Experience: Effects of Membrane Material on Nutritional Status and Dialysis-Related Symptoms. Clinical Kidney Journal, 3, i28-i35. https://doi.org/10.1093/ndtplus/sfq034

[18] Smart, N.A., Dieberg, G., Ladhani, M. and Titus, T. (2014) Early Referral to Specialist Nephrology Services for Preventing the Progression to End-Stage Kidney Disease. Cochrane Database of Systematic Reviews, No. 6, CD007333. https://doi.org/10.1002/14651858.CD007333.pub2

[19] Maduell, F., Ramos, R., Varas, J., Martin-Malo, A., Molina, M., Pérez-Garcia, R., et al. (2016) Hemodialysis Patients Receiving a Greater Kt Dose than Recommended Have Reduced Mortality and Hospitalization Risk. Kidney International, 90, 1332-1341. https://doi.org/10.1016/j.kint.2016.08.022

[20] Djukanović, L., Dimković, N., Marinković, J., Andrić, B., Bogdanović, J., Budošan, I., et al. (2015) Compliance with Guidelines and Predictors of Mortality in Hemodialysis. Learning from Serbia Patients. Nefrología, 35, 287-295. https://doi.org/10.1016/j.nefro.2015.02.003

[21] El-Sheikh, M. and El-Ghazaly, G. (2016) Assessment of Hemodialysis Adequacy in Patients with Chronic Kidney Disease in the Hemodialysis Unit at Tanta University Hospital in Egypt. Indian Journal of Nephrology, 26, 398-404. https://doi.org/10.4103/0971-4065.168141

[22] Kimata, N., Karaboyas, A., Bieber, B.A., Pisoni, R.L., Morgenstern, H., Gillespie, B.W., et al. (2014) Gender, Low Kt/V, and Mortality in Japanese Hemodialysis Patients: Opportunities for Improvement through Modifiable Practices. Hemodialysis International, 18, 596-606. https://doi.org/10.1111/hdi.12142

[23] Lertdumrongluk, P., Streja, E., Rhee, C.M., Park, J., Arah, O.A., Brunelli, S.M., et al. (2014) Dose of Hemodialysis and Survival: A Marginal Structural Model Analysis. American Journal of Nephrology, 39, 383-391. https://doi.org/10.1159/000362285 
[24] Vanholder, R., Glorieux, G. and Eloot, S. (2015) Once upon a Time in Dialysis: The Last Days of Kt/V? Kidney International, 88, 460-465. https://doi.org/10.1038/ki.2015.155

[25] Schinstock, C.A., Albright, R.C., Williams, A.W., Dillon, J.J., Bergstralh, E.J., Jenson, B.M., et al. (2011) Outcomes of Arteriovenous Fistula Creation after the Fistula First Initiative. The Clinical Journal of the American Society of Nephrology, 6, 1996-2002. https://doi.org/10.2215/CJN.11251210

[26] Ozeki, T., Shimizu, H., Fujita, Y., Inaguma, D., Maruyama, S., Ohyama, Y., et al. (2017) The Type of Vascular Access and the Incidence of Mortality in Japanese Dialysis Patients. Internal Medicine, 56, 481-485.

https://doi.org/10.2169/internalmedicine.56.7563

[27] da Silva, G.M., Gomes, I.C., Andrade, E.I.G., Lima, E.M., de Acurcio, F.A. and Cherchiglia, M.L. (2011) Permanent Vascular Access in Patients with End-Stage Renal Disease, Brazil. Revista de Saúde Pública, 45, 241-248. https://doi.org/10.1590/S0034-89102011005000005

[28] US Renal Data System (2016) USRDS 2016 Annual Data Report: Atlas of Chronic Kidney Disease and End-Stage Renal Disease in the United States. National Institutes of Health, National Institute of Diabetes and Digestive and Kidney Diseases, Bethesda, MD.

[29] Noordzij, M., Jager, K.J., van der Veer, S.N., Kramar, R., Collart, F., Heaf, J.G., et al. (2014) Use of Vascular Access for Haemodialysis in Europe: A Report from the ERA-EDTA Registry. Nephrology Dialysis Transplantation, 29, 1956-1964. https://doi.org/10.1093/ndt/gfu253

[30] Shahdadi, H., Balouchi, A., Sepehri, Z., Rafiemanesh, H., Magbri, A., Keikhaie, F., et al. (2015) Factors Affecting Hemodialysis Adequacy in a Cohort of Iranian Patient with End-Stage Renal Disease. Global Journal of Health Science, 8, 55781. https://doi.org/10.5539/gjhs.v8n8p50

[31] Hole, B., Caskey, F., Evans, K., Fluck, R., Kumwenda, M., Steenkamp, R., et al. (2017) UK Renal Registry 19th Annual Report: Chapter 12 Multisite Dialysis Access Audit in England, Northern Ireland and Wales in 2015 and 2014 PD One-Year Follow-up: National and Centre-Specific Analyses. Nephron, 137, 269-296. https://doi.org/10.1159/000481374

[32] Magalhães, L.P. (2016) Análise dos fatores preditores de mortalidade em pacientes incidentes em hemodiálise. Doctoral Thesis, Universidade de São Paulo, São Paulo. http://www.teses.usp.br/teses/disponiveis/5/5148/tde-02052016-095052/

[33] Grima, M.J., Vriens, B., Holt, P.J. and Chemla, E. (2018) An Arterioarterial Prosthetic Graft as an Alternative Option for Haemodialysis Access: A Systematic Review. The Journal of Vascular Access, 19, 45-51. https://doi.org/10.5301/jva.5000808

[34] Donca, I.Z. and Wish, J.B. (2012) Systemic Barriers to Optimal Hemodialysis Access. Seminars in Nephrology, 32, 519-529. https://doi.org/10.1016/j.semnephrol.2012.10.002

[35] Zimbudzi, E., Samlero, R., Kerr, P.G. and Zoungas, S. (2016) How Much Is Enough? An Investigation of the Relationship between Haemodialysis Adequacy and Quality of Life of Elderly Patients: Dialysis Dose and Quality of Life in the Elderly. Nephrology, 21, 314-320. https://doi.org/10.1111/nep.12594

[36] Miller, J.E., Kovesdy, C.P., Nissenson, A.R., Mehrotra, R., Streja, E., Van Wyck, D., et al. (2010) Association of Hemodialysis Treatment Time and Dose with Mortality and the Role of Race and Sex. American Journal of Kidney Diseases, 55, 100-112. 
https://doi.org/10.1053/j.ajkd.2009.08.007

[37] Daugirdas, J.T., Greene, T., Chertow, G.M. and Depner, T.A. (2010) Can Rescaling Dose of Dialysis to Body Surface Area in the HEMO Study Explain the Different Responses to Dose in Women versus Men? Clinical Journal of the American Society of Nephrology, 5, 1628-1636. https://doi.org/10.2215/CJN.02350310

[38] Ye, Y., Liu, H., Chen, Y., Zhang, Y., Li, S., Hu, W., et al. (2018) Hemoglobin Targets for the Anemia in Patients with Dialysis-Dependent Chronic Kidney Disease: A Meta-Analysis of Randomized, Controlled Trials. Renal Failure, 40, 671-679. https://doi.org/10.1080/0886022X.2018.1532909

[39] Teixeira, F.I.R., Lopes, M.L.H., dos Silva, G.A.S. and Santos, R.F. (2015) Survival of Hemodialysis Patients at a University Hospital. Jornal Brasileiro de Nefrologia, 37, 64-71. https://doi.org/10.5935/0101-2800.20150010 